\title{
KARAKTERISTIK SISTEM PERTANIAN ALAMI (Natural Farming) PADI LADANG DI KECAMATAN MOROTAI TIMUR
}

\author{
Ranita Rope \\ Staf Pengajar FAPERTA UMMU-Ternate, e-mail: -
}

\begin{abstract}
ABSTRAK
Trand dunia dengan konsep back to nature, terutama negara maju dengan korbanan triliun nilainya, hanya ingin mengembalikan lahan-lahan pertanian yang telah tercemar akibat penggunaan teknologi revolusi hijau. Apabila secara alami di lestarikan Konsep pertanian alami, maka sistem pertanian alami memiliki karakteristik sangat ekonomis, karena meminimalkan penggunaan input (hanya terdirir dari benih dan tenaga kerja). Motivasi petani untuk tetap melestarikan sistem pertanian alami padi ladang karena nilai yang melekat pada hasil panen (beras) yang disebut Tamo Majou. Tamo artinya beras, Majou adalah Tuhan, yang dipahami oleh petani bahwa Tuhan adalah Penguasa Segalanya tidak ada yang bisa Menyamai-Nya, sehingga nilai pangan yang dihasilkan dari hasil panen pertanian alami padi ladang adalah beras nomor satu yang tidak ada bandingnya. Istilah lain yang dikenal adalah Tamo Maloha yang artinya beras terbaik. Nilai tradisi lainnya yang melekat pada produk (beras) yang dihasilkan oleh sistem pertanian alami padi ladang adalah merupakan bahan baku olahan untuk sajian adat seperti Waji, isi proco sigi, dll. Sehingga dapat disimpulkan bahwa sistem pertanian padi ladang yang dikembangkan oleh petani di desa Mira memiliki karakteristik sistem pertanian alami yang dijadikan model sistem pertanian masa depan.
\end{abstract}

Kata Kunci: Jagung Pulut dan Pupuk Kalium

\section{PENDAHULUAN}

\subsection{Latar Belakang}

Morotai Timur pulau Morotai kabupaten Halmahera Utara Propinsi Maluku Utara memilki Luas wilayah $362,8 \mathrm{~km} 2$ dari 2314,9 km2 luas wilayah pulau Morotai, terletak antara $128^{\circ} 15^{\prime}-128^{\circ} 48^{\prime} \mathrm{BT}$ dan $2^{\circ} 00^{\prime}-2^{\circ} 40^{\prime}$ LU. Morotai Timur terdiri dari desa Sabatai Tua, Daeo, Jububu, Sambiki, Sangowo, Rahmat, Mira dan Wewemo dengan ibukota kecamatan berada di desa Sangowo. Keadaan topografi kurang dari 300 meter DPL dengan jenis tanah aluvial dan berbukit. Ciri iklim tropis dengan temperatur yang tinggi dan merata karena berada dibawah garis katulistiwa, jumlah kelembaban udara yang tinggi, kekuatan angin yang rendah, curah hujan rata-rata 1500-2000 mm per tahun. Curah hujan tertinggi pada bulan Mei dan terendah pada bulan Oktober. Sedangkan bulan
Agustus, September dan Oktober adalah bulan kering. (BPS, 2008).

Secara umum pulau Morotai mengalami curah hujan yang senantiasa turun sepanjang tahun dan dapat dikatakan konstan, dilihat dari terdapat hutan-hutan yang hijau atau hutanhutan hujan (rain-forest) yang subur dan hijau. Tipe hutan tropis pulau Morotai mirip dengan Sulawesi Utara dengan jenis phisionomi, terdiri dari hutan-hutan heterogen dengan pepohonan tinggi, hijau dan lebat pada tanah-tanah subur dan lembab, misalnya di Minahasa terdapat sekitar 600 jenis pohon, 200 jenis tetumbuhan menjalar, 400 jenis semak ditambah lagi dengan 100 jenis pepohonan yang tumbuh pada tempat-tempat pegunungan sampai pada pepohonan tinggi kurang lebih 40-50 meter. Bahkan pohon menjalar seperti rotan tingginya dapat mencapai 1000-1500 meter. 


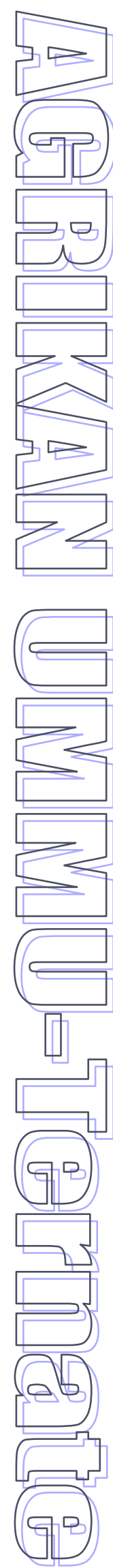

Tanaman-tanaman hutan yang pokok untuk kebutuhan produksi dan konsumsi bagi manusia adalah damar, rotan, beberapa jenis kayu seperti kayu besi, sagu, kelapa, bambu, cengkih, pala, dan tanaman pangan diantaranya padi ladang, pisang, ubi kayu, ubi jalar dan gandum yang seluruhnya bejenis variatas lokal. Di pesisir pantai juga dihiasi berbagai karakteristik tumbuhan hutan sebagai pagar hijau dengan jenis rhizophora, combretacceae, meliaceae, rubiceae, acathaceaedan palmae (Baretta,1917).

Padi (Oriza sativa $L)$ adalah jenis tanaman serealia yang dibudidayakan di lahan kering, sawah dan lahan pasang surut, dengan syarat tumbuh pada ketinggian lahan sampai 1300 meter di atas permukaan laut, dan membutuhkan suhu rata-rata 28-38 $0 \mathrm{C}$ dan membutuhkan sinar matahari yang cukup.(Soemartono dalam Sianipar,2000). Dalam berbagai literatur dijelaskan juga bahwa tanaman padi apakah padi sawah maupun padi ladang membutuhkan cukup air pada fase-fase tertentu, sehingga dalam tahap penanaman padi biasanya dilakukan pada musim hujan. Biasanya untuk padi ladang dilakukan penanaman sekali dalam setahun dan menurut Visser (1984) bahwa para petani di Sahu Kecamatan Morotai Timur biasanya melakukan penanaman pada bulan Agustus dan September, sejalan dengan itu Baretta (1917) sebelumnya juga telah menjelaskan bahwa suku Alifuru yang merupakan penduduk asli Halmahera dan Morotai biasanya masuk hutan pada bulan Agustus dan September untuk melakukan kegiatan bercocok tanam baik tanaman pangan maupun lainnya. Padi sawah dapat dilakukan tiga kali dalam setahun, misalnya dilakukan oleh petani di kabupaten Sragen, sebagaimana yang diuraikan oleh Abdullah(2007) bahwa pada penanaman musim I, berlangsung dari bulan November hingga Februari, sedangkan pada musim II biasanya berlangsung dari bulan Maret hingga Juni , dan pada musim III, biasanya berlangsung pada bulan Juli hingga Oktober, dan ini berlangsung setiap tahun.

Secara fisiologi tanaman padi dalam tahapan-tahapan pertumbuahan dikenal dengan beberapa fase, yakni fase vegetatif dan generatif. Ditandai dengan munculnya

berbagai organ tanaman, seperti akar,batang, daun,bunga dan biji. Fukuoka (1978) menjelaskan bahwa ada teori tentang tanaman padi jika terdapat daun ke empat yang menunjukan paling panjang berarti tanaman itu paling baik pertumbuhannya dan akan memberikan produksi yang baik, tetapi kenyataannya di lapangan menjelaskan lain bahwa pada daun kedua atau jika menunjukan paling panjang diantara yang lain berarti tanaman itulah yang memperlihatkan pertumbuhan yang baik dengan demikian hasilnya juga pasti baik dengan melihat jumlah batang per tanaman dan jumlah butir per malai yang terbanyak.

Kondisi alam khususnya topografi daratan kecamatan Morotai Timur, sangat mendukung para petani padi ladang tetap eksis melastarikan system pertanian alami padi ladang hingga saat ini. Dibandingkan daerah lain yang cenderung mengembangkan tanaman tanaman yang rakus hara, sehingga menciptakan system pertanian yang tidak alami dan sangat tergantung pada unsure-unsur kimia. Kecenderungan Petani di kecamatan Morotai perlu mendapat perhatian untuk terus dikembangkan dan dilestarikan.

Trand dunia saat ini dengan konsep back to nature, terutama Negara maju dengan korbanan triliun nilainya, hanya ingin mengembalikan lahan-lahan pertanian yang telah tercemar akibat penggunaan teknologi revolusi hijau. Oleh Fukuoka (1978) seorang professor mikrobiologi yang berasal dari Jepang, jauh sebelumnya dalam bukunya "The One Straw Revolution, An Introduction to Natural Farming", telah memperkenalkan konsep pertanian alami. Fukuoka dianggap sebagai ilmuan anti teknologi. Konsep pertanian alami sebenarnya sangat ekonomis, karena meminimalkan penggunaan input (benih dan tenaga kerja). Hasil penelitian membuktikan bahwa sistem pertanian alami padi ladang sangat minimal dalam penggunaan input jika dibandingkan dengan sitem pertanian anorganik ataupun organik. (Tabel 1).

Dengan demikian, sistem pertanian alami penting untuk dikaji tentang karakteristiknya sebagai model sistem pertanian masa depan. 


\subsection{Tujuan Penulisan}

Penulisan ini bertujuan untuk membahas tentang karakteristik sistem pertanian alami padi ladang.

\section{PEMBAHASAN}

\subsection{Potensi Petani Dan Pertanian}

Petani di Indonesia lebih dekat dalam pengertian peasant seperti yang didefinisikan oleh Eric R. Wolf (Abar,2002) yakni orang desa yang bercocok tanam dan beternak untuk memenuhi kebutuhan hidup sehari-hari mereka dan menunaikan surplus sosial dan ritualnya. Surplus yang dimiliki oleh petani, yakni hasil yang tidak dikonsumsi untuk kebutuhan keluarga, apabila dijual ke pasar hasilnya tetap dalam konteks untuk pemehuhan kebutuhan dasar mereka yang lain seperti, minyak tanah, garam, lauk-pauk, dll. Apabila petani bergeser menjadi farmer atau pengusaha pertanian yang terlibat dalam proses komersialisasi, petani tetap menjadi pihak yang dirugikan bahkan menjerumuskan petani kedalam kemiskinan yang semakin parah (Penny dalam Abar, 2002).

Tabel 1. Penggunaan jumlah dan jenis input pada produksi pertanian alami padi ladang dan padi sawah yang tidak alami

\begin{tabular}{|c|c|c|c|c|c|c|}
\hline \multirow[b]{2}{*}{ Uraian } & \multicolumn{2}{|c|}{ Mean } & \multicolumn{2}{|c|}{ Standar Deviasi } & \multirow[b]{2}{*}{$\mathrm{t}$ hitung } & \multirow[b]{2}{*}{ Sig } \\
\hline & Padi Ladang & $\begin{array}{l}\text { Padi } \\
\text { Sawah }\end{array}$ & $\begin{array}{c}\text { Padi } \\
\text { Ladang }\end{array}$ & Padi Sawah & & \\
\hline $\begin{array}{l}\text { Total produksi per } \\
\text { hektar } \\
\text { jumlah }\end{array}$ & 3629.6528 & 6354.4376 & 67.98472 & 2110.01821 & -7.961 & 0.00 \\
\hline perhektar & 29.1875 & 35.3297 & 1.76438 & 5.28492 & -7.092 & 0.00 \\
\hline jumlah pupuk & 0 & 127.8122 & 0 & 258.37029 & -3.476 & 0.01 \\
\hline jumlah pestisida & 0 & 0.6852 & 0 & 0.27309 & -15.322 & 0.00 \\
\hline $\begin{array}{l}\text { jumlah tenaga kerja } \\
\text { pengalaman }\end{array}$ & 361.18 & 534.6145 & 51.21735 & 165.34588 & -6.514 & 0.00 \\
\hline berusahatani & 16.5417 & 16 & 11.40727 & 0 & 0.195 & 0.85 \\
\hline
\end{tabular}

Sutriono dkk., (2006) menyatakan bahwa petani adalah manusia yang berusaha mengatur atau mengusahakan tumbuh-tumbuhan dan hewan serta memanfaatkan hasilnya. Mosher (Suratiyah,2006) menggolongkan petani sebagai pelaku usahatani kedalam tiga golongan, diantaranya petani sebagai menejer, sebagai juru tani dan petani sebagai manusia biasa. Petani sebagai menejer akan berhadapan dengan berbagai alternatif yang harus diputuskan mana yang harus dipilih untuk diusahakan. Petani harus menentukan jenis tanaman atau ternak yang akan diusahakan, menentukan cara-cara berproduksi, menentukan cara-cara pembelian sarana produksi, dan pengalaman yang akan berpengaruh dalam proses pengambilan keputusan. Petani sebagai juru tani harus dapat mengatur, melaksanakan dan mengawasi kegiatan usahataninya, baik secara tekhnis maupun ekonomis. Di samping itu, tersedianya sarana produksi dan peralatan akan menunjang keberhasilan petani sebagai juru tani. Petani sebagai anggota masyarakat yang hidup dalam suatu ikatan keluarga akan selalu berusaha memenuhi kebutuhan keluarganya. Di samping itu, petani juga harus berusaha memenuhi kebutuhan masyarakat atas diri dan keluarganya. Sebaliknya, petani juga membutuhkan bantuan masyarakat sekelilingnya. Besar kecilnya kebutuhan bantuan terhadap masyarakat sekelilingnya tergantung pada teknologi yang digunakan dan sifat masyarakat setempat. Dalam prakteknya, peranan-peranan tersebut saling kait mengkait, tetapi pasti ada salah satu yang menonjol. Sebagai contoh, pada suatu daerah tidak terdapat jenis komoditi $a, b, c$, padahal sebetulnya sangat cocok dengan iklim dan jenis tanah setempat dan harganya pun cukup tinggi. Setelah diteliti ternyata komoditas $a, b, c$ tersebut tidak umum diusahakan, bahkan tabu bagi daerah tersebut. Hal ini menunjukan bahwa peranan petani sebagai menejer sangat lemah, tetapi peranan petani sebagai anggota masyarakat yang menonjol. Oleh karena itu, 


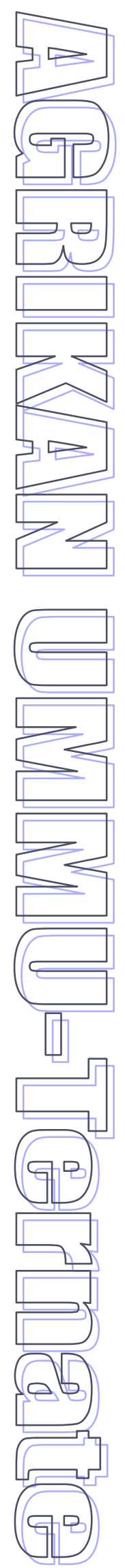

petani selalu dihadapkan pada berbagai permasalahan dalam pengambilan keputusan secara tepat.

Suratiyah (2006) menjelaskan bahwa petani biasanya melakukan berbagai alternatif dalam menghadapi berbagai permasalahan dalam pengambilan keputusan diantaranya, 1) secara intuisi yaitu berdasarkan pada keyakinan dan perasaan sendiri, 2) memohon kepada kekuatan gaib misalnya jika ditimpa kesulitan air meminta hujan dengan melakukakn sembahyang, 3) memohon kekuatan duniawi seperti memohon bantuan dukun, 4) secara akal sehat yaitu mendasarkan diri pada pengetahuan dan kemampuan sendiri yang menurut pendapatnya merupakan keputusan yang paling tepat tanpa mendengar pendapat orang lain, 5) secara logika murni, yaitu dengan kemampuan sendiri, membuat beberapa alternatif lalu menimbang-nimbang dan akhirnya mengambil satu keputusan yang tepat dan sesuai.

Hal-hal tersebut masih dilakukan oleh sebagian besar petani di Indonesia, karena disebabkan oleh beberapa faktor diantaranya; 1) kurangnya pengetahuan petani mengenai perubahan harga baik harga faktor produksi maupun produksinya, 2) kurang pengetahuan mengenai teknologi mutakhir, 3)kurangpengetahuanmengenai pemasaran, 4) kurang pengetahuan mengenai pembiayaan jangka pendek maupun jangka panjang, 5).Kurang pengetahuan mengenai; factorroduc trelationship,facto-rfactor relationship, product-product relationship dan timerelationship.

Kaitannya dengan kurangnya pengetahuan bagi petani, berhubungan langsung dengan tingkat pendidikan yang telah dilalui oleh petani, menurut Sukirno(1978) ada beberapa faktor yang menyebabkan perlunya mengembangkan tingkat pendidikan dalam usaha untuk membangun suatu perekonomian. Pertama, pendidikan yang lebih tinggi akan dapat memperluas pengetahuan masyarakat dan mempertinggi rasionalitas pemikiran mereka. Hal tersebut memungkinkan masyarakat mengambil langka yang lebih bijaksana dalam bertindak atau mengambil keputusan, Kedua, pendidikan memungkinkan masyarakat mempelajari pengetahuan-pengetahuan teknik yang diperlukan untuk memimpin dan menjalankan perusahaan modern dan kegiatankegiatan modern lainnya, Ketiga, pengetahuan yang lebih baik yang diperoleh dari pendidikan dapat menjadi perangsang untuk menciptakan pembaharuan pembaharuan dalam bidang teknik, ekonomi dan dalam berbagai aspek kehidupan masyarakat lainnya. Tingkat pendidikan yang lebih tinggi akan dapat menjamin perbaikan yang terus berlangsung pada tingkat teknologi yang digunakan masyarakat.

Akan tetapi, sesungguhnya setinggi apapun tingkat pendidikan, dan seluas apapun pengetahuan seseorang tentang sesuatu hal, ada keterbatasan yang mengungkap bahwa manusia, termasuk para ilmuwan dan petani, adalah makhluk yang sesungguhnya tidak dapat memahami alam secara baik atau seutuhnya, sehingga pemahaman terhadap alam selama ini hanya sepotong-sepotong, yang pada akhirnya dalam pengambilan keputusan terhadap penggunaan sumberdaya alam pun tidak seutuhnya (Fukuoka,1978). Sesunguhnya esensi yang harus diperhatikan adalah tujuan utama petani dalam pertanian, bagaimana memenuhi kebutuhan hidupnya, dengan memperhatikan aspek sosial budaya, ekologi dan ekonomi. Memahami serta menerapkan tiga aspek tersebutpun masih banyak permasalahan yang tidak terselesaikan hingga saat ini. Sistem pertanian terus mengalami perubahan, baik pengalaman bertambah, jumlah penduduk meningkat dan menurun, peluang dan aspirasi baru muncul, maupun basis sumberdaya alam memburuk atau membaik, sehingga usaha terus-menerus dilakukan untuk menyesuaikan dengan kondisi yang baru. Penyesuaian ini tidak selalu tepat dan akibatnya berbagai budaya secara keseluruhan mengalami disintegrasi.

Reijntjes dkk., (1992) mendapatkan bahwa banyak masyarakat pertanian yang terus bertahan hidup dalam beberapa kasus, berkembang pesat dengan mengeksploitasi basis sumberdaya alam yang telah dimanfaatkan oleh nenek moyang mereka dari generasi ke generasi. Melalui suatu proses pembaruan dan adaptasi, petani asli setempat telah mengembangkan berbagai macam sistem pertanian, dimana-mana tiap sistem pertanian 


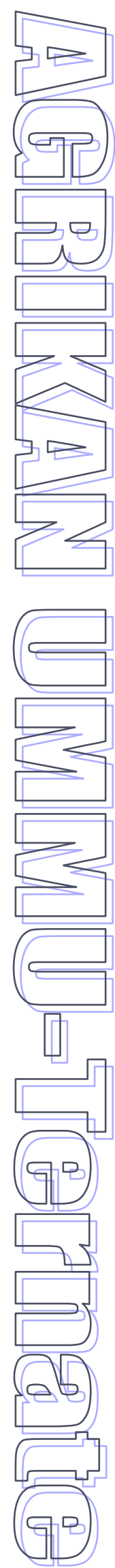

tersebut sering disesuaikan dengan lingkungan ekologis, ekonomi, sosiokultural dan politis, dengan harapan dapat mencapai hasil maksimum, baik produktivitas, keamanan, kesinambungan maupun identitas sebagai petani dalam melakukan aktivitas pertaniannya.

Sejumlah contoh-contoh sistem pemanfataan lahan lokal setempat yang di jelaskan oleh Reinjtjes dkk., (1992) yang merupakan bentuk-bentuk pertanian yang menjadi kekuatan petani yang pernah dikembangkan, yakni diantaranya: 1) Kebun hutan, misalnya hutan masyarkat desa telah ada di Jawa sejak abad ke 9 dan terdiri atas $15 \%$ $50 \%$ dari total lahan desa yang dibudidayakan. Hutan jenis ini menghasilkan berbagai macam produk dengan nilai gizi yang tinggi (misalnya buah-buahan, sayuran, daging, telur), dan produk-produk lainnya seperti kayu bakar, kayu untuk bangunan dan obat-obatan. Lebih lanjut dijelaskan bahwa dalam satu desa bisa mencapai 250 spesies yang dikembangkan secara tumpangsari oleh masyarakat desa tersebut. Selain tumbuhan ada juga hewan yang dikembangkan secara bersama dalam sebuah lahan tertentu misalnya kambing dan digembalakan secara lepas maupun ada yang dikandangkan. Sejalan dengan itu Michon (Reijntjes dkk.,1992) menjelaskan bahwa sistem pertanian seperti itu adalah merupakan suatu proses alami daur dari air dan bahan organik yang dipertahankan, karena daun-daun dan ranting yang berguguran dibiarkan membusuk hingga tetap menjaga lapisan atas tanah dengan seresah dan humus sebagai tempat daur ulang unsur hara. Kompos, lumpur kolam ikan dan pupuk hijau secara umum dimanfaatkan pada lahan pertanian. Bentuk-bentuk daur ulang ini cukup memadai untuk mempertahankan kesuburan tanah tanpa pemanfaatan pupuk buatan. Para warga desa mengatur atau memodifikasikan berfungsinya dan dinamika tiap tanaman serta hewan didalam sistem itu, 2) Ladang berpindah. Sistem pertanian berpindah merupakan sistem yang telah dan masih dipraktekan di seluruh dunia, untuk mengelola kesuburan tanah. Ladang berpindah mencakup suatu pergiliran antara tanaman musiman dan masa bera panjang dengan hutan. Lebih lanjut dijelaskan oleh Reijntjes bahwa prinsip perladangan yang khas adalah hutan ditebang, dan dibakar untuk membuka lahan dan menyediakan "pupuk" atau "kapur" untuk tanaman. Ladang berpindah ini seringkali bercirikan urutan tanaman dari musim ke musim yang berbeda kebutuhan unsur haranya dan kerentanannya terhadap gulma dan hama. Sebagaimana yang dijelaskan oleh Conklin (Reijntjes dkk.,1992) bahwa suku hanunoo di Filipina menanam padi dan jagung pada tahun pertama setelah hutan dibuka, kemudian tanaman umbi umbian seperti ubi jalar, singkong, dan umbi lain dan akhirnya pisang, yakni pisang manila (Musa textilis), bambu dan buah-buahan.

Lebih lanjut di jelaskan oleh Reijntjes dkk., (1992) bahwa dalam praktek-praktek ladang berpindah di seluruh dunia sangatlah beragam, namun pada dasarnya ada dua sistem, diantaranya : 1) sistem parsial, yang berkembang khususnya di mana kepentingan ekonomi produsen tinggi, misalnya dalam bentuk pertanian dengan tanaman perdagangan, transmigrasi maupun penempatan lahan secara liar, 2) sistem integral, yang berasal dari cara hidup yang lebih tradsional yang menjamin keberlangsungan sepanjang tahun. Dalam dunia pertanian bila tekanan penduduk tidak melampaui daya dukung suatu daerah dengan tingkat teknologi yang ada, maka ladang berpindah dengan sistem integral akan memberikan keseimbangan yang baik antara manusia dan lingkungannya. Mubyarto(1995) mengakui bahwa memang banyak persoalan yang dihadapi dalam dunia petani dan pertanian, namun pertanian bagi petani bukan lagi sekedar way of life (cara hidup), tetapi lebih dari itu merupakan bagian dari hidupnya.

\subsection{Prinsip Pertanian Alami Dan Sistem Perladangan}

Ada yang beranggapan bahwa istilah antara sistem pertanian alami dan organik adalah sama. Sutanto (2002) menjelaskan istilah antara pertanian alami dengan pertanian organik, prinsipnya sangat berbeda. Prinsip pertanian alami mengisyaratkan kekuatan alam mampu mengatur pertumbuhan tanaman. Pertanian organik campur tangan manusia lebih intensif untuk memanfatkan lahan dan 


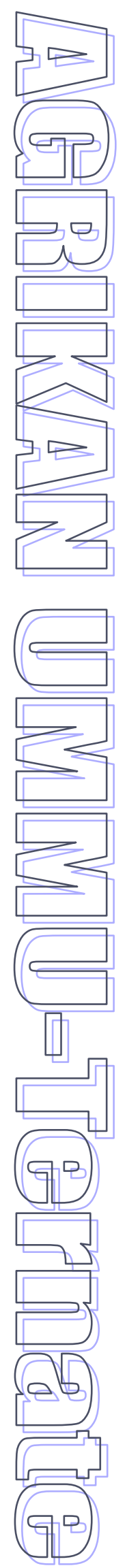

berusaha meningkatkan hasil berdasarkan prinsip daur-ulang yang dilaksanakan sesuai dengan kondisi setempat.

Metode pertanian alami memerlukan lebih sedikit tenaga daripada metode lain manapun. Metode dimaksudkan tidak menimbulkan polusi dan tidak memerlukan penggunaan bahan bakar fosil. Oleh sebab itu, ada empat azas (prinsip) pertanian alami menurut Fukuoka (1978), yaitu : 1) Tanpa olah tanah. Pada prinsipnya tanah mengolah sendiri, baik menyangkut masuknya perakaran tanaman maupun kegiatan mikrobia tanah, mikro fauna dan cacing tanah. Sebagaimana dijelaskan oleh Utomo (Evizal dkk.,1997) bahwa sistem tanpa olah tanah lebih mampu mempertahankan kesuburan tanah sehingga dalam jangka panjang mampu mempertahankan produktivitas lahan. Manfaat ekonomis yang diperoleh dari sistem ini adalah penggunaan tenaga kerja dan biaya produksi berkurang serta memperpendek periode penyiapan lahan, sehingga produktivitas lahan meningkat. 2) Tidak digunakan sama sekali pupuk kimia. Tanah dibiarkan begitu saja dan tanah dengan sendirinya akan memelihara kesuburannya. Hal ini mengacu pada proses daur-ulang tanaman dan hewan yang terjadi di bawah tegakan hutan, karena pertanian alami adalah sistem pertanian yang tanpa pupuk walaupun pupuk organik sekalipun, sistem pertanian alami meyakini bahwa lahan yang memiliki sejumlah organisme tanah yang dibutuhkan oleh tanaman akan berfungsi mengembalikan tingkat kesuburan tanah secara alami. Dan itu dianggap sebagai kodrat alam (sunatullah). Jadi unsur hara yang ada dalam tanah tidak akan pernah habis, sekalipun telah diserap oleh tanaman dalam satu periode hidup tanaman tertentu, sehingga tidak perlu ada penambahan pupuk sekalipun pupuk organik. 3) Tidak dilakukan pemberantasan gulma baik melalui pengolahan tanah maupun penggunaan herbisida. Pemakaian mulsa jerami, tanaman penutup tanah maupun menggenangan sewaktu-waktu akan membatasi dan menekan pertumbuhan gulma. 4) Sama sekali tidak tergantung pada bahan kimia. Sinar matahari, hujan dan tanah merupakan kekuatan alam yang secara langsung akan mengatur keseimbangan kehidupan alami.
Pandangan tersebut tidak berarti petani harus pasif terhadap kehendak alam akan tetapi pertanian harus tunduk pada alam dan bukan sebaliknya. Petani harus menanam jenis tanamannya tiap tahun atau bulan disesuaikan perubahan-perubahan cuaca, populasi serangga, kondisi tanah dan banyak faktor alam lainnya. Karena alam di mana-mana berubah terus, kodisinya tidak pernah persis sama setiap tahun bahkan bulan. Hal ini berimplikasi pada bagaimana mengelola kearifan lokal yang didukung oleh kebijakan desentralisasi pertanian di daerah.

Prinsip-prinsip pertanian alami tersebut sebenarnya merupakan tradisi sistem pertanian dunia yang hingga saat ini masih diterapkan di beberapa negara Asia dan Afrika, seperti di Laos, India, Tanzania dan beberapa negara lainnya termasuk Indonesia. Sistem pertanian tersebut dikenal dengan sistem perladangan, atas kepentingan ilmiah yang semakin menitik beratkan pada sistem pertanian dan teknologi yang dikembagkan di daerah setempat. Sistem pertanian dan teknologi tersebut dilihat sebagai suatu sumber gagasan yang pantas, kultivar yang beradaptasi serta praktek-praktek yang bisa mengarah pada pemanfaatan sumberdaya setempat secara berkelanjutan. Menurut Reijnjtes dkk.,(1992) pengetahuan lokal pada suatu masyarakat tani yang tinggal dalam suatu daerah khusus berasal dari pengalaman masyarakat setempat dalam bertani masa lalu, baik itu diturunkan dari generasi sebelumnya maupun dari generasi yang sekarang. Ketika teknologi yang dikembangkan di tempat lain telah dipadukan oleh petani setempat sebagai suatu bagian integral sistem pertanian mereka, maka akan menjadi satu bagian pengetahuan lokal setempat, seperti teknologi yang dikembangkan mereka sendiri. Pengetahuan praktis petani tentang ekosistem setempat, tentang sumberdaya alam dan bagaimana mereka berintegrasi tercermin dalam teknik pertanian mereka dan dalam keterampilan mereka memanfaatkan sumberdaya alam untuk memenuhi kebutuhan hidup mereka.

Namun, pengetahuan lokal setempat lebih dari apa yang tercermin dalam metodemetode teknis. Pengetahuan lokal juga memerluan wawasan, persepsi, dan intuisi 


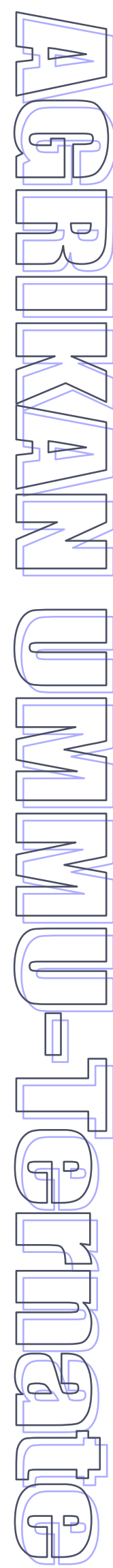

yang berhubungan dengan lingkungan meteorologi dan geologi. Ini merupakan kebijaksanaan rakyat dan biasanya menyatu dengan sistem kepercayaan dan norma budaya serta terungkap dalam tradisi dan mitos. Selain itu, metode komunikasi tradisional, misalnya melalui nyanyian atau peribahasa, serta struktur organisasi tradisional dan kerja sama sosial membentuk bagian sistem pengetahuan setempat. Sistem pengetahuan seperti ini tidak mudah dipahami oleh orang yang telah terlatih dengan ilmu pengetahuan barat (Thrupp dalam Reijnjtes dkk.,1992).

Sistem perladangan yang pernah ada di Indonesia, yang kini hampir punah, karena pemerintah lebih cenderung memberikan perhatian penuh pada sistem sawah beririgasi, sebenarnya adalah tradisi dunia yang masih terpelihara pada daerah-daerah tertentu di Indonesia. Morotai misalnya, adalah salah satu daerah yang hingga kini masih dikembangkan sistem perladangan secara turun temurun yang masih terpelihara keasliannya hingga kini. Menurut Bareta(1917) sistem perladangan yang dikembangkan di Halmahera dan Morotai oleh suku Alifuru adalah tidak menganut metode perkebunan. Ini kemudian di jelaskan secara detail oleh Heuting (Bareta, 1917) bahwa sistem perladangan tersebut dilakukan pada bulan Agustus atau September, para petani masuk ke hutan untuk membuat kebun. Pohon-pohon ditebang lalu di bakar, atau membersihkan bekas kebun yang lama yang sudah ditumbuhi kembali dengan semak-semak. Pada areal lahan yang dibakar setelah dibersihkan ditanami jagung. Setelah jagung di panen lahan kemudian dibersihkan kembali untuk melanjutkan penanaman padi ladang. Lebih lanjut dijelaskan oleh Bareta (1917) bahwa Belanda telah berusaha meningkatkan cara berfikir orang Alifuru, tetapi perubahan yang dirasakan hanya pada bidang perkebunan tanaman keras, yang pada umum sudah mengalami kemajuan. Tetapi pada sistem perladangan boleh dikata sangat lambat bahkan hampir tidak mengalami perubahan. Dengan demikian, sistem perladangan yang dikembangkan di Morotai hingga kini benarbenar tidak terjamah oleh tehnologi revolusi hijau. Pada beberapa daerah lainnya di Indonesia juga masih tetap dilakukan sistem pertanian padi ladang, tetapi ada yang sudah terjamah oleh teknologi modern seperti di Sumatera (Sianipar, 2000).

\subsection{Deskripsi Sistem usahatani secara umum}

Usahatani tidak terlepas dari budaya dan sejarah. Peluang dan hambatan ekologis dan geografis mengenai lokasi, iklim, tanah, tumbuhan, dan hewan setempat tercermin dalam budaya setempat. Hal ini kemudian tercermin dalam pertanian setempat yang merupakan hasil dari suatu proses interaksi antara manusia dan sumber daya setempat. Nilai-nilai masyarakat pedesaan, pengetahuan, ketrampilan, teknologi dan institusi sangat mempengaruhi jenis budaya pertanian yang telah dan terus berkembang (Reijntjes dkk.,1992).

Usahatani pada prinsipnya sama dalam berbagai sistem pertanian. Namun setiap usahatani perseorangan memiliki sumberdaya fisik, bilogis, dan manusia yang berbeda, sehingga Reijnjtes dkk., (1991) menyatakan bahwa tiap-tiap usahatani itu merupakan suatu sistem usahatani yang unik yang memiliki ciri khas baik dari aspek tata letak biofisik, dan tata letak manusia. Maksud dari tata letak biofisik adalah bahwa sumberdaya genetik, teknik dan strategi yang bisa dipilih oleh petani dalam menciptakan, mempertahankan, dan mengembangkan sistem usahatani, sebagian besar ditentukan oleh ciri khas dari ekosisitemnya, seperti ekosistem pegunungan, dangkal, asin, dan lain-lain. Petani pada umumnya telah meneliti dengan sebaikbaiknya pilihan-pilihan yang disesuaikan dengan keadaan setempat dan memanfaatkannya dengan baik, sehingga sistem pertanian yang serasi telah berkembang dan mampu bertahan dari generasi ke generasi. Dengan demikian jika dalam memperluas pengembangan sistem pertanian berkelanjutan ke daerah kritis, terpencil, beragam dan pinggiran, harus memahami implikasi kekhasan biofisik yang ada.

Terlepas dari tata letak biofisiknya, sistem usahatani juga memiliki ciri khas tata letak manusia, yakni yang digambarkan oleh Reijnjtes dkk., (1992) bahwa suatu sistem pertanian juga ditentukan oleh ciri-ciri sosioekonomi, budaya dan politik, lebih-lebih 


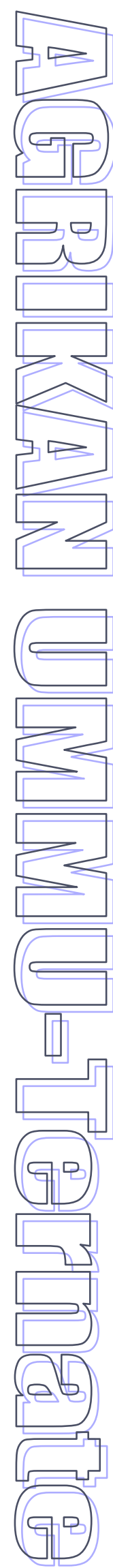

yang berhubungan dengan kerumahtanggaan petani. Setiap rumahtangga merupakan sebuah gabungan yang unik antara laki-laki dan perempuan, orang dewasa dan anak-anak yang semuanya memberikan penggolongan, pengetahuan, tenaga kerja, modal, dan lahan untuk usahatani dan yang mengkonsumsi paling tidak sebagian dari hasil usahataninya. Jadi rumahtangga petani merupakan pusat alokasi sumberdaya, produksi dan konsumsi. Lebih lanjut, dijelaskan oleh Reijntjes dkk., (1992) bahwa rumahtangga itu bisa terdiri dari beberapa subsistem yang kurang lebih otonom, seperti istri dengan subrumahtangga dan atau usahatani. Melalui hubungan luarnya, rumahtanga berfungsi dalam konteks sistem ekonomi, sosial, budaya dan politik yang lebih luas, tetapi juga mempengaruhi sistem sistem ini. Hubungan luar ini, misalkan lewat pasar atau media massa, juga mempengaruhi rumahtangga dan berikutnya sistem usahataninya. Ikatan dengan masyarakat bisa kuat, misalnya, ikatan keluarga, persahabatan, sejarah, dan budaya umum serta pengawasan umum terhadap wilayah bisa saling menghubungkan sistem usahatani perorangan. Anggota masyarakat sering memanfatkan lahan bersama dan saling memberi dukungan dengan saling berbagi dan menukar tenaga kerja, hewan,lahan atau hasil-hasil pertanian. Interaksi ini berfungsi sebagai pembendung risiko dan merupakan bagian dari strategi keluarga atau individu untuk mempertahankan hidup. Anggota keluarga yang lain bisa saja terlibat dalam berbagai jaringan kerja dalam masyarakatnya sendiri maupun antarmasyarakat, sehingga tata letak manusia bersifat dinamis. Oleh karena itu, untuk memahami sistem usahatani, perlu mengetahui apa yang telah dan sedang berubah yaitu perkembangan sejarah dan penyebab serta pengaruhnya.

Prisip-prinsip ekonomi dalam ilmu ekonomi juga telah memberikan dasar perencanaan usahatani dan pemilihan alternatif usaha. Agar dapat memperoleh kemampuan dalam mengelola hidup secara baik. Konsep Law of comparative advantage, misalnya, yaitu konsep tentang keunggulan dalam perbandingan. Konsep ini menjelaskan bahwa langkah pertama yang harus diambil petani dalam berusaha adalah mempelajari dan menemukan faktor-faktor fisik dan ekonomi yang memberikan keunggulan kepada desa atau daerahnya secara umum dan pada tanahusahanya secara khusus,dibandingkan dengan daerah lain, dengan usaha lainnya. Keunggulan ini mungkin timbul karena kedudukan geografi, kedudukan topografi, atau hubungannya dengan faktor-faktor ekonomi maupun sosial.

Langkah selanjutnya yang akan diambil oleh petani adalah dengan memahami hukum Prinsip Substitusi yakni mengajarkan pada petani agar dalam berusahatani untuk mencapai tujuan tertentu menggunakan caracara yang membutuhkan biaya yang paling murah dalam memperoleh hasil yang sama. Karena tiap tujuan usaha dapat dicapai melalui lebih dari satu dengan mendatangkan hasil yang sama, akan tetapi masing-masing cara mempunyai pola dan taraf pembiayaan yang berbeda antara satu dengan lainnya.

\subsection{Karakteristik Sistem Pertanian Alami Padi Ladang \\ Penduduk Morotai Timur sebagian besar} bekerja sebagai petani dan nelayan, lainnya adalah pekerja srabutan, pegawai negeri dan swasta. Tradisi atau kebiasaan yang dilakukan dalam berusahatani alami hampir sama dengan tradisi bertani alami padi ladang yang digambarkan dalam referensi-referensi dibeberapa negara seperti Philipina, Afrika, laos dan India. Beberapa ritual yang mencirikan sistem pertanian alami juga hampir sama dengan sistem ladang berpindah yang dilakukan oleh masyarakat adat suku dayak. Motivasi petani untuk tetap melestarikan sistem pertanian alami padi ladang karena nilai yang melekat pada hasil panen (beras) yang disebut Tamo Majou. Tamo artinya beras, Majou adalah Tuhan, yang dipahami oleh petani bahwa Tuhan adalah Penguasa Segalanya tidak ada yang bisa MenyamaiNya, sehingga nilai pangan yang dihasilkan dari hasil panen pertanian alami padi ladang adalah beras nomor satu yang tidak ada bandingnya. Istilah lain yang dikenal adalah Tamo Maloha yang artinya beras terbaik. Nilai tradisi lainnya yang melekat pada produk (beras) yang dihasilkan oleh sistem pertanian alami padi 


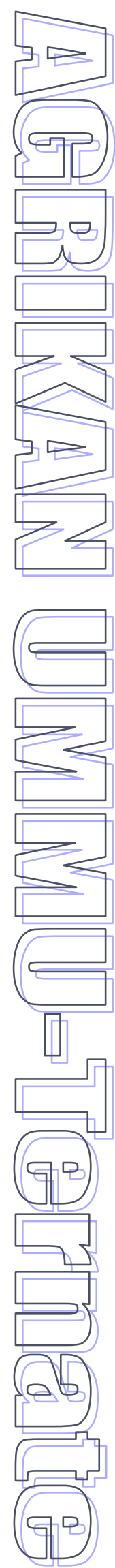

ladang adalah merupakan bahan baku olahan untuk sajian adat seperti Waji, isi proco sigi, dll.

Tahapan-tahapan yang dilakukan dalam tradisi sistem pertanian alami padi ladang yang dikembang oleh petani di kecamatan Morotai Timur yaitu persiapan benih (gisisi), pembersihan lahan, penanaman, perawatan dan panen.

\subsubsection{Persiapan Benih (gisisi)}

Benih adalah simbol dari kehidupan bagi tanaman. Benih juga merupakan salah satu input terpenting dalam proses produksi tanaman. Tanpa benih walau input lainnya tersedia namun tidak akan terjadi proses produksi suatu usahatani tanaman. Begitu pentingnya peran benih maka setiap petani sadar akan arti pentingnya ketersediaan benih. Bagi petani pertanian alami padi ladang di Morotai Timur dan beberapa daerah di Halmahera menyebut benih sebagai gisisi. Gabah padi dari hasil panen yang diperuntukan untuk kebutuhan konsumsi bukan merupakan gisisi tetapi disebut tamo. Gisisi memiliki beberapa jenis yang semuanya adalah tergolong varietas lokal diantaranya gisisi menyan, thathua maboro, malewa, pulo Irian, siang, dodore, campaka dan lain-lain. Semua jenis varietas bukan saja dibedakan oleh jenis nama tetapi nilai yang melekat pada jenis benih tertentu. Nilai yang melekat pada jenis benih tertentu karena didasari atas jenis rasa beras yang dihasilkan dari budidaya benih tersebut, dan mudah tidaknya ditumbuk pada saat hasil panen gabah menjadi beras.

Petani memiliki ketrampilan dalam memilih benih yang berkualitas. Bagi petani pemula memperoleh benih dari petani lain dengan cara dibeli atau dipinjam dengan perjanjian yang mengikat. Petani yang bukan pemula biasanya menyediakan benih sendiri dari hasil budidaya sebelumya. Pemilihan benih dari tanaman padi yang siap panen dilakukan sejak masa pertumbuhan. Petani telah mengamati dari awal pertumbuhan vegetatifnya hingga masuk fase generatif. Petani punya keahlian dalam menghubungkan jenis pertumbuhan vegetatif seperti apa bakal menghasilkan bulir gabah yang padat dan berkualitas untuk dijadikan benih. Benih yang berkualitas menurut petani responden adalah benih yang gabahnya padat berisi, mengkilap dan tidak ada bekas gigitan serangga atau jenis hama. Areal yang menjadi sumber benih tidak dipanen oleh tenaga luar, tetapi dilakukan oleh petani dalam keluarga agar tetap terjaga untuk tidak tercampur dengan gabah lainnya. Benih yang sudah dipanen dan dilepaskan gabah dari batang bulirnya, kemudian dijemur dalam beberapa jam lalu disimpan dalam kaleng atau petani menyebutnya dengan blek hitam besar. Atau sesuai jumlah benih yang tersedia. Masa penyimpanan hingga kurang lebih 7 bulan mendatang.

\subsubsection{Persiapan Lahan}

Tahapan selanjutnya dalam tradisi bertani alami padi ladang adalah persiapan lahan yang terdiri dari tahap paras, bakar, dan pembersihan. Kegiatan persiapan lahan yang selama ini berlangsung pada petani responden adalah hanya dilakukan dengan tenaga kerja keluarga. Petani sudah harus merencanakan pada saat musim hujan tiba, maka 2 bulan sebelumnya petani sudah harus masuk kebun untuk mulai melakukan aktifitas persiapan lahan tanam. Dengan mengandalkan tenaga kerja keluarga yang biasanya hanya terdiri dari suami istri dengan proporsi pekerjaan yang suda turun temurun melekat dalam tradisi persiapan lahan. Paras dilakukan oleh laki-laki, setelah paras dilakukan dibiarkan 1-2 hari kemudian dilakukan kegiatan bakar rumput bisa dilakukan oleh laki-laki atau perempuan atau dilakukan bersama-sama. Setelah kegiatan bakar rumput selesai dilakukan pembersihan rumput sisa-sisa pembakaran biasanya perempuan lebih ahli dalam melakukan tahapan pembersihan tetapi untuk mempercepat proses pembersihan jika waktu tanam sudah tiba maka biasanya dilakukan bersama-sama . Tetapi jika musim tanam diperkirakan masih lama maka biasanya yang menyelesaikan adalah perempuan atau istri. Suami biasanya melakukan aktifitas lain seperti mempersiapkan bahan "Pola" atau sebutan lumbung tradisional untuk penampungan dan penyimpanan hasil panen. Setelah pembersihan, lahan siap untuk dilakukan penanaman.

Alat yang digunakan dalam persiapan lahan tanam hanya golok yang disebut parang atau taito untuk laki-laki dan kuda-kuda atau 


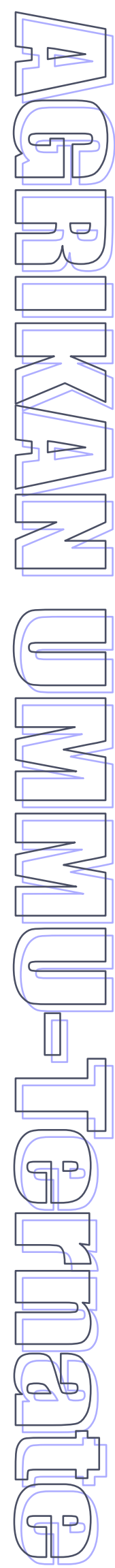

sionga untuk perempuan, kuda-kuda adalah sejenis golok yang berbeda bentuknya dengan parang (lihat gambar lampiran).

\subsubsection{Penanaman}

Kegiatan penanaman dilakukan dengan kebiasaan pembagian kerja antara laki-laki dan perempuan. Untuk kebutuhan tenaga kerja bervariasi tetapi rata-rata kebutuhan 1 hektar membutuhkan tenaga kerja Laki-laki 15 orang bertugas membuat lubang tanam dengan sebatang kayu yang berdiameter kurang lebih 3-4 cm dengan panjang kurang lebih $1.50 \mathrm{~m}$ hingga $2 \mathrm{~m}$. Perempuan berjumlah 7 orang yang mengisi benih dilubang-lubang tanam yang tersedia. Jumlah benih biasanya antara $4-6$ butir per lubang tanam. Alat yang dibutuhkan selain kayu untuk membuat lubang tanam juga tempat benih. Tetapi tempat benih tidak terlalu dipersolkan jenisnya yang terpenting benih tidak berserakan akibat rusaknya tempat benih tersebut. Yang menjadi kebiasaan dan hingga kini tetap dilakukan petani adalah ada ritual yang dilakukan pada saat penanaman. Dahulu bagi suku alifuru yang beragama animisme percaya bahwa masyarakat asli morotai adalah yang kini disebut "orang moro" akibat dibunuh secara massal sehingga arwahnya bergentayangan dan memiliki tempat sendiri yang abstrak oleh penglihatan manusia. Mereka percaya bahwa arwah-arwah ini akan membantu mereka dalam melakukan aktivitas bertaninya, tetapi telah terjadi perubahan ketika masyarakat telah menganut agama terutama agama Islam ritualnya sudah berbeda dengan yang dilakukan dahulu. Ritualnya ketika proses tanam dilakukan harus ada seseorang yang dituahkan yang dianggap mampu atau dipercaya harus melakukan kegiatan tanam dahulu dengan membaca doa tertentu (ayat-ayat alquran), setelah itu serentak bersama-sama melakukan tradisi bertanam. Laki-laki membuat lubang tanam dan diikuti oleh perempuan yang mengisi benih dilubang tanam tersebut.

Ada kepercayaan pada masyarakat tersebut, jika salah memilih orang yang dituahkan untuk mendahului melakukan aktifitas penanaman tersebut maka biasanya yang terjadi adalah proses penanaman tidak bisa selesai dalam sehari dan tenaga kerja baik laki-laki maupun perempuan merasa cepat lelah dan benih juga biasanya tidak cukup dalam proses penanaman tersebut. Akibatnya tanaman mungkin akan tumbuh tidak sesuai dengan yang diharapkan.

Tahapan penanaman membutuhkan tenaga kerja luar namun tidak diupah secara tunai, tetapi tradisi yang berlangsung dan dilakukan hingga penelitian dilakukan adalah hanya memberikan makan pada tenaga kerja yang ikut membantu. Ada kesepakatan bahwa kebiasaan ini dikenal dengan aturan "pinjam tangan" artinya petani lain yang pernah membantu dalam proses penanaman maka petani yang telah dibantu harus balik memberikan bantuan yang sama.

\subsubsection{Perawatan}

Setelah benih ditanam, kegiatan selanjutnya adalah perawatan, biasanya jika benih yang ditanam itu baik maka dalam seminggu benih sudah mulai tumbuh. Tahap ini yang membedakan juga dengan sistem pertanian lainnya, pada sistem pertanian lain ada perlakuan-perlakuan lain seperti pemupukan dan pemberian pestisida, tetapi pada sistem pertanian alami padi ladang tidak dilakukan kegiatan tersebut. Apabila terjadi serangan hama seperti hama wereng, petani biasanya sudah lebih awal tahu karena senantiasa mengamati pertumbuhan tanaman padi yang sudah tumbuh. Petani dalam sholat shubuhnya membaaca doa qunut dan diniatkan agar cara yang dilakukan nantinya diridhoi oleh Allah SWT. Setelah sholat shubuh biasanya petani ada yang membawa pasir putih dari pantai, setelah tawaf pada kebun ladang tersebut, petani melemparkan pasir tersebut sebagai syarat mengusirnya, dan sebagian petani lagi menangkap hama tersebut dan melepaskan racun atau bisa yang dimiliki hama wereng tersebut kemudian dilepas tanpa membunuh hama tersebut dengan kepercayaan hama wereng tersebut tidak akan mampu merusak padi mereka karena tidak lagi memiliki kemampuan merusak. Timbul pertanyaan zat apa yang dikandung oleh pasir putih yang diambil petani dari pantai sehingga selama ini dipercaya ampuh membunuh hama wereng?racun atau bisa apa yang dimiliki oleh hama tersebut sehingga dengan melepaskan racun atau bisa maka hama tersebut tidak mempunyai kemampuan merusak. Mungkin 


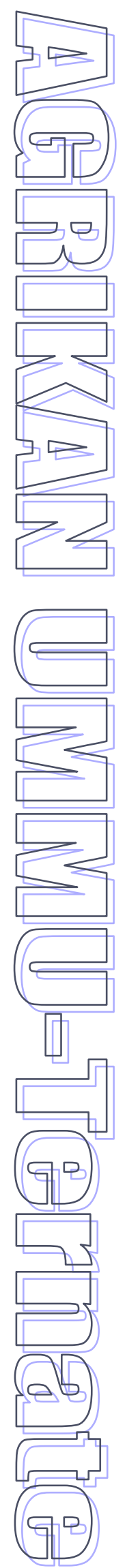

perlu ada penelitian dari pihak hama penyakit untuk melihat manfaat kegitan yang biasa dilakukan oleh petani tersebut.

Pengamatan secara ekstra dilakukan pada saat tanaman padi sudah masuk pada fase generatif. Selanjudnya petani terus menjaga dan mengamati pada lahan yang sudah memasuki fase generatif tersebut, pihak perempuan sambil menunggu masa panen sudah mempersiapkan alat penampungan hasil saat panen seperti pigu dan tatapa (lihat gambar dokumentasi penelitian). Tidak ada tenaga kerja luar yang digunakan dalam tahap kegiatan perawatan.

\subsubsection{Panen}

Panen adalah puncak kegiatan berusahatani. Tahapan ini membutuhkan tenaga kerja luar yang disesuaikan dengan luas lahan yang ditanami padi ladang. Suku alifuru yang beragama animisme biasanya melakukan ritual pada saat panen dengan menyediakan sesajian tertentu, dan hal ini masih melekat dan dilakukan hingga saat ini. Bagi mereka ini adalah wujud rasa syukur atas nikmat Tuhan. Bagi yang beragama Islam hanya membuat sesajian untuk dimakan bersama-sama tenaga kerja luar yang ikut kegiatan panen, sebelumnya dilakukan baca doa bersama-sama. Tetapi bagi yang percaya pada arwah orang moro maka sesajian diletakan di tempat tertentu, kemudian kegiatan panen dilakukan. Alat yang dibutuhkan adalah ani-ani (gugutu), pigu, dan tatapa.

\subsection{Karakteristik Petani Padi ladang}

Penduduk Desa Mira berjumlah 292 kepala keluarga, dan aktif berusahatani padi ladang alami musim tanam Desember 2007 Mei 2008 hanya 48 petani. Total luas lahan 64.5 ha dengan produksi total mencapai $232,250 \mathrm{~kg}$. Produktivitas padi ladag alami mencapai 3.63 ton/ha Tingkat produktivitas yang dicapai sudah merupakan prestasi luar biasa bagi sistem pertanian yang tetap menggunakan input alami, diantaranya benih varietas lokal dan tidak menggunakan teknologi modern seperti benih unggul, bahan kimia baik Urea,Kcl,Tsp dan pestisida yang merupakan paket revolusi hijau. Hal ini didukung oleh karakteristik petani dalam berusahatani alami padi ladang. Karakteristik petani responden yang mencakup umur, pendidikan formal, pengalaman berusahatani, jumlah anggota keluarga dan luas lahan. Sebagai nilai kontrol yang dijadikan pembanding dalam melihat aktifitas bertani alami padi ladang maka usahatani padi sawah yang dikenal sebagai usahatani yang tingkat ketergantungannya terhadap teknologi moderen sangat tinggi, dijadikan sebagai sampel pembandingnya, berjumlah 17 responden dari desa Wewemo.

\subsubsection{Umur}

Umur seseorang menentukan prestasi kerja, sebagaimana dijelaskan Suratiyah (2006), bahwa prestasi kerja atau kinerja orang dipengaruhi oleh umur. Semakin berat pekerjaan secara fisik maka semakin tua tenaga kerja akan semakin turun pula prestasinya. Lebih lanjut dijelaskan bahwa dalam hal memenuhi tanggungjawab maka semakin tua umur tenaga kerja tidak akan berpengaruh karena justru semakin berpengalaman. Sisi lain, ada yang mengklasifikasikan menjadi umur produktif dan tidak produkstif. Budiyono (1990) menggolongkan kisaran umur antara 10 hingga 60 tahun masih merupakan umur produktif jika dilihat dari prestasi kerja dalam lamanya melakukan aktifitas berusahatani.

Karakteristik petani responden padi ladang alami yang diwawancarai rata-rata terbanyak diatas umur 45 hingga 66 tahun. Keadaan umur petani responden terlihat dalam Tabel 2. Keadaan umur yang menjadi karakteristik petani ladang alami tersebut tidak bisa diinterpretasi karena perlu ada penelitian lanjutan kearah tersebut. Kenyataan dilapangan yang terjadi bahwa petani dengan kisaran umur rata-rata bervariasi tersebut dapat melakukan usahatani sesuai kebiasaan bartani yang berlangsung. Ukuran fisik dapat dijelaskan bahwa topografi lahan pertanian yang berbukit tidak menjadi masalah bagi petani responden dengan kisaran umur 56-66 tahun. Dari aspek produktivitas yang dicapai juga tidak dapat dijadikan penilaian spesifik. Umur lebih berkaitan pada aspek ketrampilan pengambilan keputusan karena lamanya berusahatani dan hal ini akan dijelaskan pada bagian pengalaman berusahatani. 


\subsubsection{Pendidikan formal}

Aktivitas manapun dilakukan, status pendidikan formal yang dicapai amat berpengaruh dalam pengambilan keputusan untuk menjadi yang terbaik. Demikian halnya dalam berusahatani padi ladang alami.

Produksi padi ladang yang menggunakan variatas lokal pada beberapa daerah menggambarkan hasil produksi yang rendah, dan tidak dikelola dengan baik karena biasanya setelah tanam lahan dibiarkan hingga pada saat tiba waktu panen kemudian petani kembali ke kebun untuk memanen hasilnya.Daerah Mira petani responden tidak melakukan hal demikian tetapi mengelola usahatani secara serius dan benar, dengan tetap mengharapkan hasil yang terbaik. Hal ini didukung oleh status pendidikan formal yang dicapai oleh petani responden. Petani responden desa Mira rata-rata melalui pendidikan formal, walau terbanyak pada tingkat pendidikan SD, tetapi dapat dijelaskan bahwa petani terbebas dari buta huruf. Data pendidikan formal petani responden terlihat dalam Tabel 3.

\subsubsection{Pengalaman Berusahatani}

Data tabel 4.3. terlihat bahwa pengalaman petani responden padi ladang alami bervariasi dari 2 hingga 43 tahun, dan persentase yang juga bervariasi. Data terlihat pada Tabel 4.

Tabel 2. Keadaan umur petani responden

\begin{tabular}{crrrr}
\hline \multirow{2}{*}{ Umur } & \multicolumn{2}{c}{ Petani padi ladang } & \multicolumn{2}{c}{ Petani padi sawah } \\
\cline { 2 - 5 } & Jumlah (orang) & Persentase (\%) & Jumlah (orang) & Persentase (\%) \\
\hline $23-33$ & 7 & 14,58 & 1 & 5,88 \\
$34-44$ & 11 & 22,92 & 8 & 47,06 \\
$45-55$ & 16 & 33,33 & 6 & 35,29 \\
$56-66$ & 14 & 29,17 & 2 & 11,76 \\
\hline Total & 48 & 100 & 17 & 100 \\
\hline Sumber: data primer diolah & & & &
\end{tabular}

Tabel 3. Data pendidikan formal petani responden

\begin{tabular}{lcccc}
\hline \multirow{2}{*}{$\begin{array}{c}\text { Pendidikan } \\
\text { formal }\end{array}$} & \multicolumn{2}{c}{ Petani padi ladang } & \multicolumn{2}{c}{ Petani padi sawah } \\
\cline { 2 - 5 } & Jumlah (orang) & Persentase (\%) & Jumlah (orang) & Persentase (\%) \\
\hline SD & 20 & 41,67 & 11 & 64,71 \\
SMP & 14 & 29,17 & 1 & 5,88 \\
SMA & 13 & 27,08 & 5 & 29,41 \\
SARJANA & 1 & 2,08 & 0 & 0 \\
\hline Total & 48 & 100 & 17 & 100 \\
\hline Sumber: data primer diolah & & & &
\end{tabular}

Tabel 4. Data pengalaman berusahatani petani responden

\begin{tabular}{ccccc}
\hline \multirow{2}{*}{$\begin{array}{c}\text { Pengalaman } \\
\text { berusahatani }\end{array}$} & \multicolumn{2}{c}{ Petani padi ladang } & \multicolumn{2}{c}{ Petani padi sawah } \\
\cline { 2 - 5 } & Jumlah (orang) & Persentase (\%) & Jumlah (orang) & Persentase (\%) \\
\hline \multirow{2}{*}{ 2-15 tahun } & 26 & 54,17 & 0 & 0 \\
$16-29$ tahun & 12 & 25,00 & 17 & 100 \\
$30-43$ tahun & 10 & 20,83 & 0 & 0 \\
\hline Total & 48 & 100 & 17 & 100 \\
\hline
\end{tabular}

Sumber: data primer diolah

Hasil wawancara menggambarkan bahwa semakin lama petani dalam menjalankan usahataninya maka petani makin terbiasa dalam menggunakan keputusan yang diambil dalam berusahatani. Terbiasa dalam pengambilan keputusan baik penggunakan benih yang berkualitas, keputusan dalam menggunakan tenaga kerja luar yang terampil 


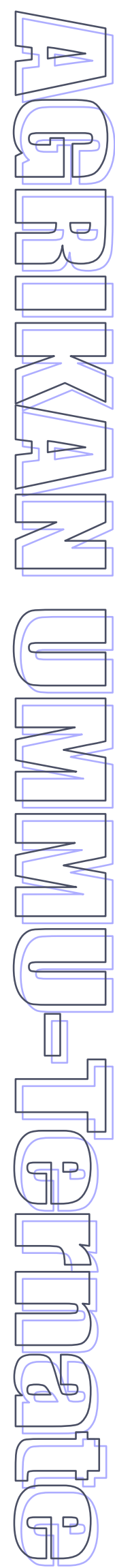

pada tahap penanaman dan panen. Kemampuan memprediksi jumlah alat dan bahan yang digunakan. Semua ini merupakan kebiasaan yang diperoleh dari pengalaman berusahatani yang berulang, rutin dan sudah bertahun-tahun dijalaninya.

Pengambilan keputusan penggunaan benih misalnya, jika petani pemula maka benih bersumber dari petani lainnya yang dalam pemilihannya tergantung pada benih yang tersedia. Bagi petani yang sudah pernah melakukan dan hendak melakukan yang kesekian kalinya maka petani yang bersangkutan sudah mampu mengambil keputusan mana sumber benih berkualitas yang digunakan untuk berusahatani berikutnya agar hasil yang dicapai maksimal.

Pengalaman petani dalam keputusan menggunakan tenaga luar yang terampil kaitannya dengan pengalaman, bahwa jumlah benih yang sama tetapi kadang cukup bagi musim tanam tertentu dan tidak cukup pada musim tanam yang lain menimbulkan kecurigaan pada tenaga kerja yang kurang terampil dalam menaruh jumlah benih pada lubang tanam. Pada saat memanenpun petani yang kurang terampil dapat menggunakan waktu panen yang cukup lama karena kurang terampil dalam menggunakan ani-ani. Dan yang terpenting dari semua keputusan adalah keputusan petani tetap dan terus dalam berusahatani dengan pengalaman yang dialaminya.

\subsubsection{Jumlah Anggota Keluarga}

Hal lain yang amat menentukan petani responden dalam berusahatani adalah jumlah anggota keluarga yang menjadi tanggungannya. Semakin banyak jumlah anggota keluarga yang terdapat dalam sebuah keluarga petani maka kebutuhan akan keluarga tersebut semakin banyak. Suratiyah (2006) menjelaskan bahwa hal yang amat menentukan dalam prestasi kerja tenaga kerja keluarga yang tidak diupah adalah besarnya kebutuhan keluarga yang wajib dipenuhi. Dapat dijelaskan bahwa semakin banyak anggota keluarga yang terdapat dalam keluarga petani maka petani sebagai tenaga kerja keluarga akan berfikir untuk bagaimana memenuhi kebutuhan keluarganya dengan melakukan aktivitas ektra untuk menyediakan kebutuhan tersebut.

Anggota keluarga yang sudah dewasa diatas umur 20 tahun atau yang sudah menikah dapat menjadi tambahan tenaga kerja keluarga, sehingga jumlah anggota keluarga yang banyak dapat mengurangi tenaga kerja luar yang dibutuhkan pada tahap penanaman dan panen. Data jumlah anggota keluarga petani responden terlihat pada Tabel 5 .

Tabel 5. Data jumlah anggota keluarga petani responden

\begin{tabular}{ccccc}
\hline \multirow{2}{*}{$\begin{array}{c}\text { Jumlah anggota } \\
\text { keluarga }\end{array}$} & \multicolumn{3}{c}{ Petani padi ladang } & \multicolumn{3}{c}{ Petani padi sawah } \\
\cline { 2 - 5 } & Jumlah (orang) & Persentase (\%) & Jumlah (orang) & Persentase (\%) \\
\hline 2-6 Orang & 37 & 77,08 & 14 & 82,35 \\
7-11 Orang & 11 & 22,92 & 3 & 17,65 \\
\hline Total & 48 & 100 & 17 & 100 \\
\hline Sumber: data primer diolah & & &
\end{tabular}

Tabel 6. Data luas lahan petani responden

\begin{tabular}{ccccc}
\hline \multirow{2}{*}{ Luas lahan } & \multicolumn{2}{c}{ Petani padi ladang } & \multicolumn{2}{c}{ Petani padi sawah } \\
\cline { 2 - 5 } & Jumlah (orang) & Persentase (\%) & Jumlah (orang) & Persentase (\%) \\
\hline$<0.5$ & 0 & 0,00 & 1 & 5,88 \\
$0.5-1$ & 32 & 66,67 & 14 & 82,35 \\
$1.5-2$ & 15 & 31,25 & 2 & 11,76 \\
$>2$ & 1 & 2,08 & 0 & 0,00 \\
\hline Total & 48 & 100 & 17 & 100 \\
\hline Sumber: data primer diolah & & & &
\end{tabular}




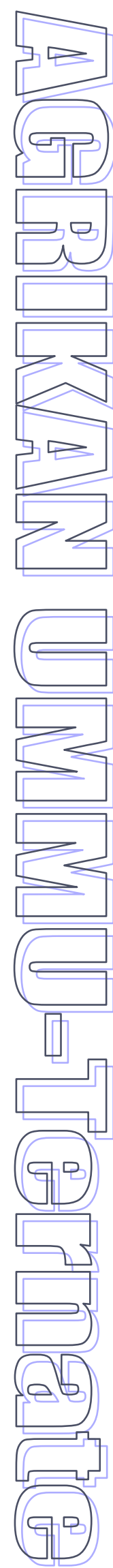

\subsubsection{Luas Lahan}

Lahan merupakan input terpenting dalam berusahatani. Usahatani tertentu sangat ditentukan oleh luas lahan. Lahan yang semakin luas mampu memberikan produksi yang tinggi jika diikuti oleh jumlah tenaga kerja dan modal yang sesuai. Lahan yang luas juga dapat menjadi masalah bagi petani jika jumlah tenaga kerja yang kurang tersedia dan modal yang tidak cukup untuk mengelolanya.

Semakin luas lahan semakin tinggi produksi yang dicapai jika diikuti oleh jumlah tenaga kerja dan modal yang sesuai, dan semakin luas lahan dapat juga menurunkan nilai produksi yang dicapai jika tidak diikuti oleh jumlah tenaga kerja dan modal yang tepat karena kurang tepat dalam mengelola lahan tersebut. Data luas lahan yang dimiliki petani responden bervariasi. Untuk petani usahatani alami padi ladang memiliki lahan sempit 1 hektar dan terluas 3 hektar. Petani responden padi sawah memiliki luas lahan sempit kurang dari 0,5 hektar dan terluas 2 hektar. Data luas lahan terdapat pada Tabel 6.

\section{PENUTUP}

Melestarikan sistem pertanian alami padi ladang di kecamatan Morotai Timur, tidak membutuhkan biaya milyaran atau triliun sebagaimana yang dilakukan oleh negaranegara maju saat ini dalam mengembalikan tingkat kesuburan lahan-lahan pertanian yang sudah tidak produktif akibat penggunaan teknologi yang rakus hara. Sistem pertaniannya memiliki karakteristik alami yang dapat dijadikan model pertanian masa depan.

\section{DAFTAR PUSTAKA}

Abar, A.Z., 2002. Petani Dalam Perspektif Antropologi Ekonomi, Agro-Ekonomi, Jurusan Sosial Ekonomi Pertanian Fakultas Pertanian UGM Yogyakarta. 9(1):38-39

Abdullah,W.G.,2007. Studi Komparatif Perilaku Petani Terhadap Resiko Usahatani Padi Non Organik dan Organik di Kabupaten Sragen, Tesis S2 Ekonomi Pertanian Universitas Gadjah Mada, Yogyakarta,Karya tidak dipublikasikan.

Adian,D.G.,2006. Pertanian dan Pengetahuan Lokal, dalam Tim Kompas, Revitalisasi Pertanian; Dan Dialog Peradaban. Cet.I;PT, Media Kompas Nusantara, Jakarta.

Anonim, 2005. Prospek Dan Arah Pengembangan Agribisnis Padi ; Badan Penelitian Dan Pengembangan Pertanian, Departemen Pertanian Jakarta.

Anonim,2011, Materi Kementrian daerah tertinggal pada workshop, Penyusunan Perda Perencanaan Pembangunan Daerah Maluku Utara, BAPEDA Propinsi Maluku Utara.

Bareta,J.M., 1917. Halmahera En Morotai, Bewerk near memorie van den Kapitein van den Generalen Staf, Nederland.

Beratha, I.N., 1982. Desa, Masyarakat Desa Dan Pembangunan Desa, penerbit Balai Aksara Yudhistira dan Saadiyah

Budiyono,A.,1990. Modernisasi Pertanian Kaitannya Dengan Keamanan Ekonomi Pedesaan 19701989: Suatu studi kasus tentang perubahan lembaga hubungan pertanahan dan lembaga hubungan kerja pertanian di Desa Rahayu Yogyakarta, Laporan untuk Toyota Foundation.

BPS,2007. Halmahera Utara Dalam Angka, Tobelo.

Clarke,W.C., 1978. Kemajuan Masa Lampau:Suatu Sistem Pertanian Tradisional Yang Menunjang Lingkungan, dalam J. Metzner, dan N. Daldjoeni, (Penyunting), Ekoforming, Bertani selaras alam, Yayasan Obor Indonesia Jakarta.

Dillon,J.L., and Hardaker,J.B., 1986. Farm Manajemen Research For Small Development, diterjemahkan oleh Soekartawi dan Soeharjo,A., dengan judul Ilmu Usahatani dan penelitian untuk pengembangan petani kecil. Penerbit Universitas Indonesia (UI-PRESS), Jakarta.

Djuwari, 2003. Ilmu Usaha Tani, Jurusan Sosial Ekonomi Pertanian Fakultas Pertanian Universitas Gadjah Mada Yogyakarta.

Evizal,R.,Sulastri,R.,dan Sugiatno,1997. Sistem Olah Tanah di Sela Perkebunan Kelapa Untuk Penanaman Padi Gogo, Tanah Tropis, Lampung ,4;145-150. 
Fukuoka, M., 1978. Revolusi Sebatang Jerami; sebuah pengantar menuju pertanian alami,.Judul asli The One-straw revolution :an introduction to natural farming, alih bahasa, Yayasan obor Indonesia , Cet.I; Yayasan Obor Indonesia, Jakarta.

Geertz, C. 1974. Involusi Pertanian, Diterjemahkan Oleh : Supomo S., Bhatara Karya Aksara Jakarta.

Husodo S.Y. 2003. Pemberdayaan Ekonomi Petani melalui LEISA. Makalah seminar nasional :pemberdayaan ekonomi masyarakat petani melalui penerapan konsep LEISA, Fakultas Pertanian UKSW Salatiga.

Janzen, D. H., 1973. Ekosistem Pertanian Tropis, dalam Metzner, J., dan Daldjoeni,N.,(penyunting) Ekoforming, Bertani selaras alam, , Yayasan Obor Indonesia Jakarta.

Luanne, L., and Timothy A. P.,2006. Agricultural and Resource Ekonomic Review;35,2 ProQuest Agriculture Jurnal.diakses pada thn 2007.

Mubyarto, 1994. Pengantar Ekonomi Pertanian, Edisi ketiga,LP3ES, Jakarta.

Planck, U 1989. Sosiologi Pertanian, diterjemahkan oleh : Soentoro S. dan Soeyanto, Yayasan Obor Indonesia Jakarta.

Rahardjo 1999. Pengantar sosiologi Pedesaan dan pertanian, Gadja Mada University Press Yogyakarta

Redfield,R.,tanpa tahun. The little Community, Peasant Society and Culture, diterjemahkan oleh Dhekidae,D.,1982., Penerbit CV Rajawali, Jakarta.

Reijntjes, C.Haverkort B, and ann Waters-bayer 1992. Farming For The future; and instroduction to low-eternal-input and sustainable agriculture, edisi Indonesia, oleh Sukoco, Y., Kanisius Yogyakarta.

Rope,R., 2007. Konsep Pertanian Alami: Sebuah Perpektif, Jurnal Sains, edisi I Volume 1, ISSN Universitas Muhammadiyah Maluku Utara.

,2008a. Analisis Usahatani Pada Sistem Pertanian Alami Padi ladang Di Kabupaten Halmahera Utara, Tesis, S2 UGM, Yogyakarta

-2008b. Analisis Usahatani Pada Sistem Pertanian Alami Padi ladang Di Kabupaten Halmahera Utara, Jurnal AGRIKAN ISSN 1979-6072 volume 2, Edisi 1. Fakultas Pertanian Universitas Muhammadiyah Maluku Utara.

Sianipar, J 2000. Efisiensi Usahatani Padi Ladang dan Jagung di lahan kering Kabupaten Karo, Tesis S2 UGM Yogyakarta.

Sianipar J. E. 2001. Efisiensi Produksi pada system usaha pertanian jagung di desa Randuacir kota Salatiga, Tesis S2 UGM Yogyakarta.

Suhartini 2007. Kajian Keberlanjutan Sistem Usahatani Padi Semi Organik di Kabupaten Sragen, Disertasi S3 UGM Yogyakarta.

Soekardono,2006. Teori Eonomi Produksi Pertanian dan Peternakan,Mataram University Press, cetakan pertama, Yogyakarta.

Soetriono,2006 Daya Saing Pertanian Dalam Tinjauan Analisis, edisi Pertama, Bayumedia Publishing, Malang.

Soetriono, Suwandari,A., dan Rijanto,2006. Pengantar Ilmu Pertanian, Agraria, Agrobisnis, dan Industri, Edisi Revisi, Bayumedia Publishing, Malang.

Sukirno,S.,1978. Ekonomi Pembanguan;Proses,Masalah dan Dasar Kebijaksanan, Penerbit Bota Gorat, Medan.

Sutanto,R., 2006. Pertanian Organik; Menuju Pertanian Alternatif dan Berkelanjutan, Cet,V; Kanisius.Yogyakarta.

Visser,L.E.,1984., Mijn Tuin Is Mijn Kind., Een antropologische studie van de droge rijstteelt in sahu (Indonesia-halut)., diterjemahkan dalam bahasa inggris dengan judul My Rice Field Is My Child, Social And Territorial Aspect of Swidden Cultivation in sahu, eastern Indonesia., oleh De Coursey, R., Foris publications Dorrecht-Holland/ Providenc U.S.A. 